\title{
SOCS2 correlates with malignancy and exerts growth-promoting effects in prostate cancer
}

\author{
Julia Hoefer, Johann Kern', Philipp Ofer, Iris E Eder, Georg Schäfer, Dimo Dietrich², \\ Glen Kristiansen ${ }^{2}$, Stephan Geley ${ }^{3}$, Johannes Rainer ${ }^{3}$, Eberhard Gunsilius', \\ Helmut Klocker, Zoran Culig and Martin Puhr \\ Experimental Urology, Department of Urology, Innsbruck Medical University, Anichstrasse 35, A-6020 Innsbruck \\ Austria \\ ${ }^{1}$ Oncotyrol Laboratory for Tumor Biology and Angiogenesis, Innsbruck, Austria \\ ${ }^{2}$ Institute of Pathology, University Hospital Bonn, Bonn, Germany \\ ${ }^{3}$ Division of Molecular Pathophysiology, Innsbruck Biocenter, Medical University Innsbruck, Innsbruck, Austria
}

Correspondence should be addressed to Z Culig or M Puhr Emails

zoran.culig@i-med.ac.at or martin.puhr@i-med.ac.at

\begin{abstract}
Deregulation of cytokine and growth factor signaling due to an altered expression of endogenous regulators is well recognized in prostate cancer (PCa) and other cancers. Suppressor of cytokine signaling 2 (SOCS2) is a key regulator of the GH, IGF, and prolactin signaling pathways that have been implicated in carcinogenesis. In this study, we evaluated the expression patterns and functional significance of SOCS2 in PCa. Protein expression analysis employing tissue microarrays from two independent patient cohorts revealed a significantly enhanced expression in tumor tissue compared with benign tissue as well as association with Gleason score and disease progression. In vitro and in vivo assays uncovered the involvement of SOCS2 in the regulation of cell growth and apoptosis. Functionally, SOCS2 knockdown inhibited PCa cell proliferation and xenograft growth in a CAM assay. Decreased cell growth after SOCS2 downregulation was associated with cell-cycle arrest and apoptosis. In addition, we proved that SOCS2 expression is significantly elevated upon androgenic stimulation in androgen receptor (AR)-positive cell lines, providing a possible mechanistic explanation for high SOCS2 levels in PCa tissue. Consequently, SOCS2 expression correlated with AR expression in the malignant tissue of patients. On the whole, our study linked increased SOCS2 expression in PCa with a pro-proliferative role in vitro and in vivo.
\end{abstract}
Key Words
- prostate cancer
- SOCS2
- androgen
- proliferation
- survival

\section{Introduction}

Prostate cancer (PCa) represents the most common malignancy in men in the Western world (Jemal et al. 2011). The development and progression of PCa are strongly associated with the dysfunction of various signaling pathways. Preserved androgen signaling is one of the main characteristics of the disease, especially in advanced and castration-resistant PCa (Locke et al. 2008,
Lonergan \& Tindall 2011). Furthermore, cytokine and growth factor signaling cascades are frequently deregulated due to an altered expression of endogenous key regulators such as protein inhibitors of activated STAT (PIAS), Src-homology 2 (SH2)-containing protein tyrosine phosphatases, and suppressors of cytokine signaling (SOCS; Larsen \& Ropke 2002, Heinrich et al. 2003, 
Tan \& Nevalainen 2008, Dutt \& Gao 2009, Puhr et al. 2009, Hoefer et al. 2012, Singh et al. 2012).

SOCS proteins have originally been described as the feedback inhibitors of cytokine-induced Janus kinase (JAK/STAT) signaling (Endo et al. 1997, Naka et al. 1997, Starr et al. 1997). However, they have also been reported to be associated with other pathways such as nuclear factor kappa B signaling (Ryo et al. 2003) and insulin signaling (Rui et al. 2002). The SOCS family consists of eight members: SOCS1-7 and cytokine-inducible SH2containing protein (CIS). They contain an N-terminal region of variable length, a central $\mathrm{SH} 2$ domain, and a conserved C-terminal region called SOCS box. SOCS members can act as E3 ubiquitin ligases toward associated proteins (Kamura et al. 1998, 2004) and are rapidly induced upon the release of multiple growth factors and cytokines, with STAT molecules being the main transducers of these signals (Croker et al. 2008).

The involvement of SOCS1 and SOCS3 in PCa has been extensively investigated and both tumor suppressive and oncogenic roles have been reported (Bellezza et al. 2006, Neuwirt et al. 2007, 2009, Puhr et al. 2009, 2010, Pierconti et al. 2011). However, to date, only a limited number of studies have investigated the expression and functional significance of SOCS2 in PCa. In other malignancies, the upregulation or downregulation of SOCS2 has already been demonstrated (Arany et al. 2001, Schultheis et al. 2002, Wikman et al. 2002, Sutherland et al. 2004). Furthermore, Socs 2 knockout as well as transgenic mice have been reported to display gigantism (Metcalf et al. 2000, Greenhalgh et al. 2002), suggesting a dual role for SOCS2 in growth regulation. SOCS2 is preferentially upregulated by growth hormone $(\mathrm{GH}$; Greenhalgh et al. 2002), erythropoietin (Starr et al. 1997, Wang et al. 2004), interleukins (ILs; Starr et al. 1997, Rico-Bautista et al. 2006), and prolactin (Pezet et al. 1999). Furthermore, SOCS2 is implicated in insulin-like growth factor (IGF) 1 and insulin signaling cascades (Dey et al. 1998, Sadowski et al. 2001). Deregulation of either of these signaling cascades has already been reported to be associated with PCa (Roberts 2004, Monti et al. 2007, Cox et al. 2009, Culig 2011, Goffin et al. 2011, Culig \& Puhr 2012, Nakonechnaya et al. 2013). Therefore, we hypothesize that SOCS2 is a crucial regulator in PCa. To address this question, in this study, we investigated SOCS2 expression in tissue samples and carried out in vitro and in vivo assays to uncover its functional relevance in PCa. Our data clearly demonstrate a growth-promoting role for SOCS2 and provide an explanation for a high SOCS2 expression in malignant tissue via androgenic regulation.

\section{Materials and methods}

\section{Tissue microarray and immunohistochemistry}

A tissue microarray (TMA) (Innsbruck-TMA) containing tissue cores obtained from $90 \mathrm{PCa}$ patients who underwent radical prostatectomy at the University Hospital Innsbruck was constructed and immunohistochemically stained as described elsewhere (Hoefer et al. 2012). In addition, SOCS2 expression in metastases was assessed using two TMAs constructed from tissue cores obtained from ten patients with lymph node and bone metastases respectively. Evaluation was done by an uropathologist (GS) using the semi-quantitative scoring system 'quickscore' (Detre et al. 1995). A second TMA (Bonn-TMA) comprising tissue specimens collected from $25 \mathrm{PCa}$ patients who underwent radical prostatectomy at the University Hospital Bonn, Germany, was constructed and stained as described above. The study was approved by the institutional review boards. Staining intensity was evaluated by an independent pathologist (V S), defining a score between 0 (negative staining) and 3 (intense staining). The following antibodies were used: anti-SOCS2 (H-74) (1:100; Santa Cruz Biotechnology) and anti-androgen receptor (AR) (1:400; Epitomics, Burlingame, CA, USA).

\section{Methylation analysis}

Bisulfite-converted DNA from FFPE tissue samples was prepared as described previously (Dietrich et al. 2012) (see Supplementary Materials and methods). Relative DNA methylation levels of the SOCS2 gene locus referred to as total DNA as determined with a methylation-unspecific $\beta$-actin $(A C T B)$ assay were assessed using a quantitative duplex PCR. PCR composition and thermal cycling were used as described previously (Dietrich et al. 2012).

\section{Cell culture and reagents}

PC3, DU145, LNCaP, BPH-1, 22RV1, DUCaP, LAPC4, RWPE-1, and VCaP cells were obtained from the American Type Culture Collection (ATCC, Rockville, MD, USA) and cultured as indicated. The DUCaP-R subline was established by cultivation in the presence of $1 \mathrm{nM}$ R1881 (Pfeiffer et al. 2010). The identity of the cell lines was confirmed by short tandem repeat analysis. Benign stromal PM151T and epithelial EP156T cells were cultured as described elsewhere (Kogan et al. 2006). For androgen stimulation, the cells were starved in RPMI containing $10 \%(\mathrm{v} / \mathrm{v})$ charcoal-stripped FCS for $24 \mathrm{~h}$ and then treated

Published by Bioscientifica Ltd. 
with R1881 (DuPont NEN Products, Boston, MA, USA). To antagonize androgen-induced effects, LNCaP cells were incubated with $5 \mu \mathrm{M}$ of bicalutamide for $24 \mathrm{~h}$. LAPC4 cells, which are usually maintained in a medium containing dihydrotestosterone (DHT), were grown in RPMI containing 10\% (v/v) charcoal-stripped FCS with or without 100 nM DHT (Sigma-Aldrich).

\section{Western blotting}

Nuclear and cytoplasmic fractions were separated using the NE-PER Nuclear and Cytoplasmic extraction kit (Thermo Scientific, Rockford, IL, USA) following the manufacturer's instructions. Western blotting was carried out as described previously (Puhr et al. 2009). The following antibodies were used: anti-SOCS2 (1:500; Cell Signaling, Danvers, MA, USA), anti-GAPDH (1:100 000; Chemicon, Vienna, Austria), anti-cPARP (1:1000, Promega), and anti-Lamin A (1:5000, Abcam, Cambridge, UK).

\section{RNA isolation and qRT-PCR}

RNA isolation, RT, and qRT-PCR were carried out as described elsewhere (Puhr et al. 2009) (see Supplementary Materials and methods).

\section{SOCS2 downregulation}

PC3, DU145, and LNCaP cells were stably transfected with doxycycline-inducible shRNA constructs containing GFP against SOCS2 (shSOCS2-1 and shSOCS2-3) or luciferase (shLuc) (see Supplementary Materials and methods). The generation and transfection of constructs have been described in Sigl et al. (2009). For functional assays, the cells were pretreated with doxycycline $(1 \mu \mathrm{g} / \mathrm{ml})$ for 6 days to achieve SOCS2 downregulation.

\section{SOCS2 overexpression}

pCMV6-AC-GFP and pCMV-AC-GFP-SOCS2 plasmids were obtained from Origene (Rockville, MD, USA). The cells were transfected with DNA $(0.5 \mu \mathrm{g} / \mathrm{six}$ wells) using $3 \mu \mathrm{l}$ of Fugene HD (Roche) for $48 \mathrm{~h}$. For stable overexpression, the cells were selected with $0.5 \mathrm{mg} / \mathrm{ml}$ of G418 (neomycin) for 7 days.

\section{Proliferation measurement}

Proliferation was assessed using $\left[{ }^{3} \mathrm{H}\right]$ thymidine incorporation assay as described in Hoefer et al. (2012). The medium was supplemented with 10\% FCS. Viability was measured by WST assay. The cells were seeded in 96-well plates and grown in the medium. To the plates, $10 \mu \mathrm{l}$ of WST reagent (Roche) were added for $60 \mathrm{~min}$. Absorbance was assessed using Chameleon 5025 (HVD Life Sciences, Vienna, Austria).

\section{Clonogenic assay}

A total of 1.500 cells (PC3 and DU145) or 10.000 cells (LNCaP) were seeded into a $75 \mathrm{~cm}^{2}$ cell-culture flask and incubated for 12 (PC3 and DU145) or 18 days (LNCaP). Colonies were stained as described in Hoefer et al. (2012).

\section{Apoptosis measurement and cell-cycle distribution}

Apoptotic cells and cell-cycle distribution were assessed as described previously (Hoefer et al. 2012) and analyzed using the ModFit LT 3.2 software.

\section{Chick chorioallantoic membrane assay}

Chick chorioallantoic membrane (CAM) assay was carried out as described (Deryugina \& Quigley 2008) with slight modifications. For onplant preparation, native, nonpepsinized type I rat tail collagen (BD Bioscience, Schwechat, Austria) was neutralized with $0.2 \mathrm{M} \mathrm{NaOH}$ solution and mixed with $10 \times$ DMEM (Life Technologies Gibco). A total of $5 \times 10^{5}$ pretreated PC3 cells were added to $50 \mu \mathrm{l}$ of this solution. Collagen onplants with or without doxycycline $(1 \mu \mathrm{g} / \mathrm{ml})$ were applied to CAMs and incubated for 5 days. Xenografts were analyzed under a stereomicroscope with a digital camera (Olympus SZX10, Olympus E410, Vienna). The tumor area was determined using ImageJ (NIH). For histological analysis, onplants were excised from the CAMs, fixed in $4 \%$ paraformaldehyde, and processed for paraffin sectioning and immunohistochemistry (IHC). The following antibodies were used: anti-SOCS2 (H-74) (1:100; Santa Cruz) and anti-Ki67 (1:100; Dako, Glostrup, Denmark).

\section{Microarray dataset generation and analysis}

The microarray dataset was generated at the Expression Profiling Unit of the Medical University Innsbruck following the manufacturer's protocols as described in Martowicz et al. (2013). The analysis of the in total 30 Affymetrix HuGene-1.0-ST-v1 GeneChips was carried out as described in Rainer et al. (2012) using functions from Bioconductor packages (Gentleman et al. 2004). The raw and pre-processed data were been submitted to GEO (accession number: GSE 50936).

Published by Bioscientifica Ltd. 


\section{Statistical analyses}

SPSS (V15.0) and GraphPad Prism 4 were used for statistical analyses. The Mann-Whitney $U$ test or $t$-test was carried out to calculate significances between two groups. Correlation analysis was carried out using Pearson's method. Differences in relapse-free survival, defined as biochemical recurrence, were assessed using the Kaplan-Meier plots and log-rank test. Differences were considered statistically significant when $P$ was $<0.05$.

\section{Results}

\section{SOCS2 expression increases with malignancy and inversely correlates with time to disease recurrence}

To evaluate SOCS2 expression patterns in benign and malignant prostate tissue, we used a radical prostatectomy specimen TMA of two independent PCa cohorts. Ninety malignant and 79 benign cores of PCa specimens obtained in Innsbruck (Innsbruck-TMA) were evaluable after immunohistochemical staining. A representative benign gland (Fig. 1A) revealed a low SOCS2 expression in the surrounding stromal compartment (especially in smooth muscle fibers), whereas epithelial cells expressed higher levels of SOCS2. Within the epithelial compartment, the basal cell layer exhibited a much more intense SOCS2 staining than luminal cells. A similar phenomenon was observed in benign epithelial and stromal prostate cell lines. We detected the highest SOCS2 expression in EP156T cells, which predominantly represent a basal epithelial phenotype (Kogan et al. 2006), lower SOCS2 expression in the phenotypically luminal epithelial RWPE-1 cells, and the weakest SOCS2 expression in the stromal cell line PM151T (Fig. 1B). Quantitative analysis of the TMA demonstrated a significantly elevated SOCS2 expression in malignant areas compared with benign tissue, as well as in high- vs lowGleason score samples (Fig. 1C and D). Furthermore, SOCS2 expression was significantly higher in bone and lymph node metastases compared with benign tissue (Fig. 1D). In primary tumor tissue, SOCS2 expression was positively correlated with the Gleason score (Fig. 1E), and relapse-free survival was significantly shorter in patients with a high SOCS2 expression (Fig. 1F). IHC staining of a second cohort of patients (Bonn-TMA) confirmed an elevated SOCS2 expression in low- as well as high-Gleason score tumors (Supplementary Figure 1, see section on supplementary data given at the end of this article). Testing for SOCS2 gene hypermethylation, which is frequently reported for other tumor entities (Sutherland et al. 2004, Culig 2013), revealed no alteration in malignant tissue (Fig. 1G), consistent with the high expression of the protein in PCa.

\section{SOCS2 expression regulates PCa cell growth in vitro and in vivo}

All the tested prostate cell lines expressed both SOCS2 mRNA and protein, as measured by qRT-PCR and western blotting respectively (Fig. 2A and B). The observed discrepancy between mRNA and protein levels indicates a tight regulation of SOCS2 protein stability via proteasomal degradation. Cellular fractionation and subsequent western blotting revealed SOCS2 expression predominantly in the cytoplasmic fraction (Fig. 2C). To uncover a possible influence of SOCS2 on cell growth, we carried out functional assays following SOCS2 depletion. For this purpose, PC3, DU145, and LNCaP cells were stably transfected with doxycycline-inducible SOCS2 shRNA constructs and treated with doxycycline for 6 days to achieve prolonged SOCS2 downregulation (Fig. 3A). Subsequent $\left[{ }^{3} \mathrm{H}\right]$ thymidine incorporation and clonogenic assays revealed a significant decrease in both proliferation (Fig. 3B) and colony formation ability (Fig. 3C) in cells in which SOCS2 was silenced. We obtained similar results with both specific shRNA sequences; however, growth inhibition with shSOCS2-1 was more prominent. The WST assay confirmed decreased cell viability after SOCS2 downregulation (Fig. 3D). In line with these findings, SOCS2 overexpression increased the proliferation and clonogenic potential in PC3 cells (Supplementary Figure 2, see section on supplementary data given at the end of this article).

To confirm a possible anti-proliferative effect of SOCS2 knockdown on tumor growth in vivo, we applied a CAM assay using PC3 shSOCS2-1 or shLuc cells. In the past three decades, the CAM assay has become an accepted and reliable in vivo model to replace animal experiments for testing different treatments (Armstrong et al. 1982, Kunzi-Rapp et al. 2001, Taizi et al. 2006, Tavaszi \& Budai 2006, Saw et al. 2008). In xenografts derived from SOCS2 knockdown cells, we observed a significantly reduced tumor area after 5 days on the CAM (Fig. 4A and D). Immunohistochemical staining revealed a reduced SOCS2 expression in the tumor cells as well as a significant decrease in the proportion of Ki67-positive cells (Fig. 4B and C).

\section{SOCS2 knockdown leads to cell-cycle arrest and increased apoptosis}

To elucidate the mechanism underlying the decreased cell growth after SOCS2 downregulation, we measured

Published by Bioscientifica Ltd. 
A

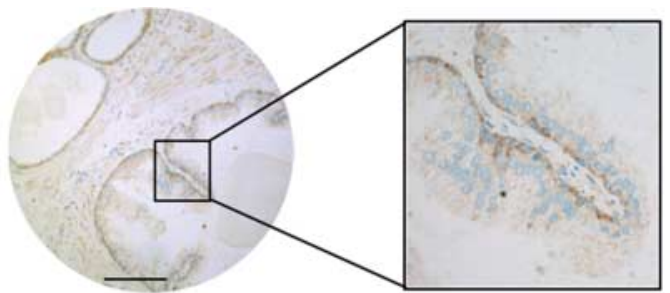

B

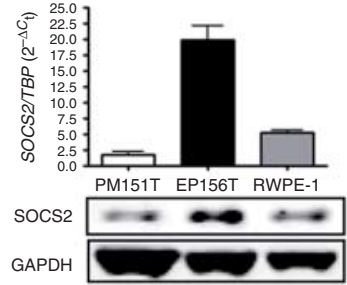

C

Benign

Low GSC

High GSC

Bone

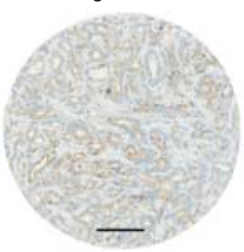

Lymph node

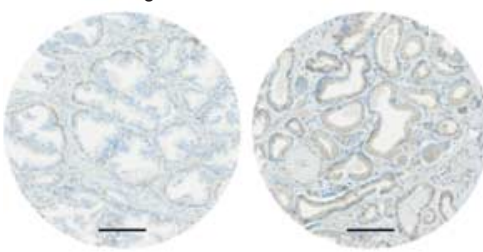

D
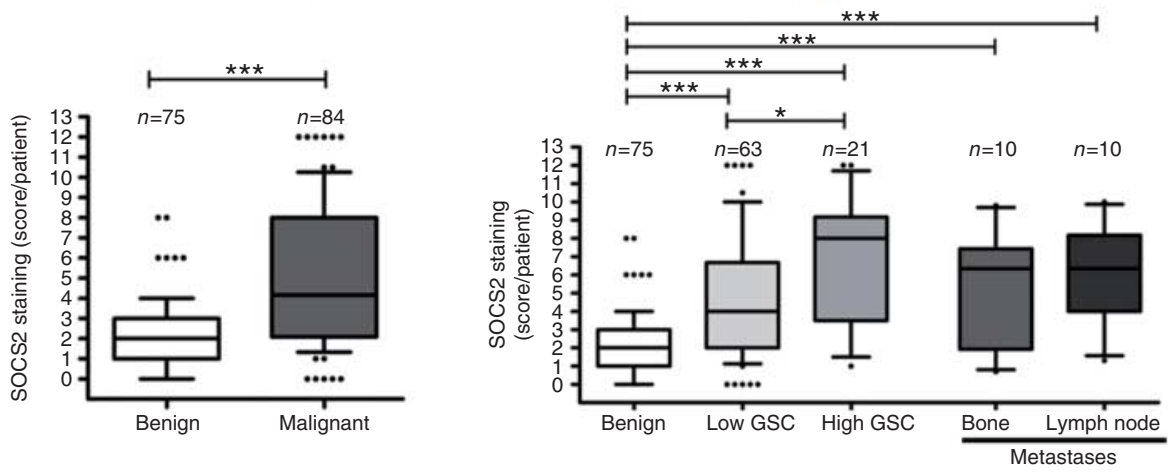

E

\begin{tabular}{|c|l|c|}
\hline \multicolumn{2}{|c|}{ Correlations } & Gleason score \\
\hline \multirow{4}{*}{ SOCS2 staining } & Correlation coefficient & $0.357^{\star \star}$ \\
\cline { 2 - 3 } & Significance (two-sided) & 0.001 \\
\cline { 2 - 3 } & $N$ & 84 \\
\hline
\end{tabular}
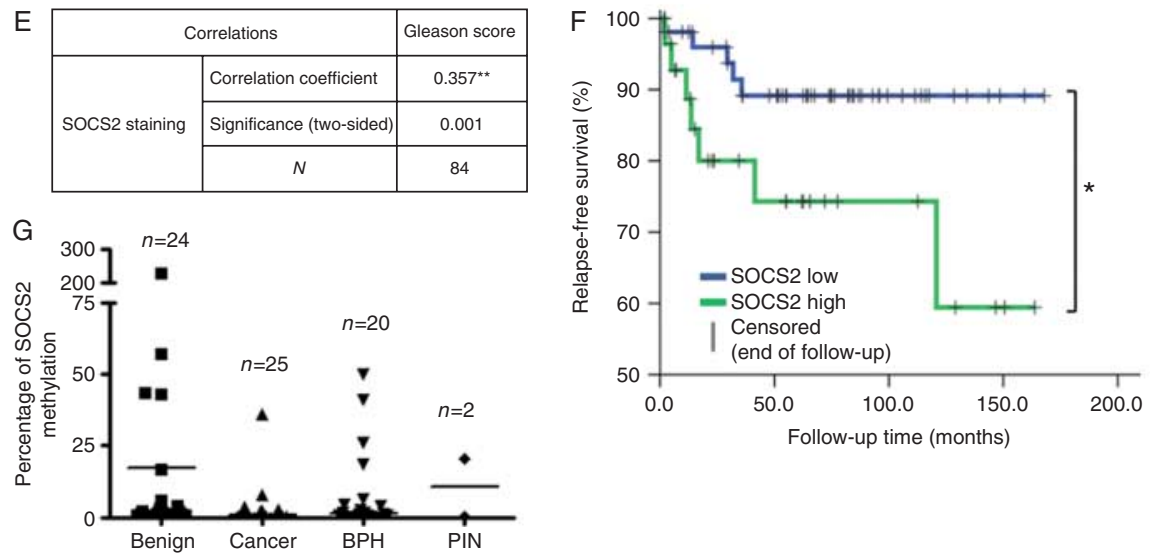

Figure 1

SOCS2 expression increases with malignancy and inversely correlates with relapse-free survival. (A) SOCS2 immunostaining of a benign prostate gland showing high SOCS2 expression in epithelial cells. Scale bar: $100 \mu \mathrm{m}$.

(B) qRT-PCR data and representative western blots of three benign prostate cell lines: PM151T (stromal), EP156T (basal epithelial), and RWPE-1 (luminal epithelial). (C) Immunohistochemical SOCS2 staining of representative tissue samples of the Innsbruck-TMAs. Scale bar: $100 \mu \mathrm{m}$. (D) Statistical analysis of the Innsbruck-TMAs. Low Gleason: Gleason patterns $3+4$ or below. High Gleason: Gleason patterns $4+3$ or above. Box-Whiskers plot represents median values and $10-90$ percentiles $(* P<0.05$ and $* * * P<0.001$;

Mann-Whitney $U$ test). GSC, Gleason score. (E) Pearson's correlation analysis results for SOCS2 and Gleason score in malignant tissue samples of the TMA. (F) Kaplan-Meier curve assessment of relapse-free survival, defined as time to PSA progression, in patients exhibiting a low SOCS2 expression $\left(N_{\text {(total) }}=52 ; N_{\text {(relapse) }}=5\right)$ vs patients exhibiting a high SOCS2 expression $\left(N_{\text {(total) }}=30 ; N_{\text {(relapse) }}=7\right)$. High SOCS2 expression represents samples with SOCS2 staining score $\geq 6$ according to the 'quickscore method' ( ${ }^{*} P<0.05$; log-rank test). (G) Methylation status of the SOCS2 gene locus was determined by qRT-PCR using methylation-specific primers. Results were normalized to $\beta$-actin and represent mean values. 

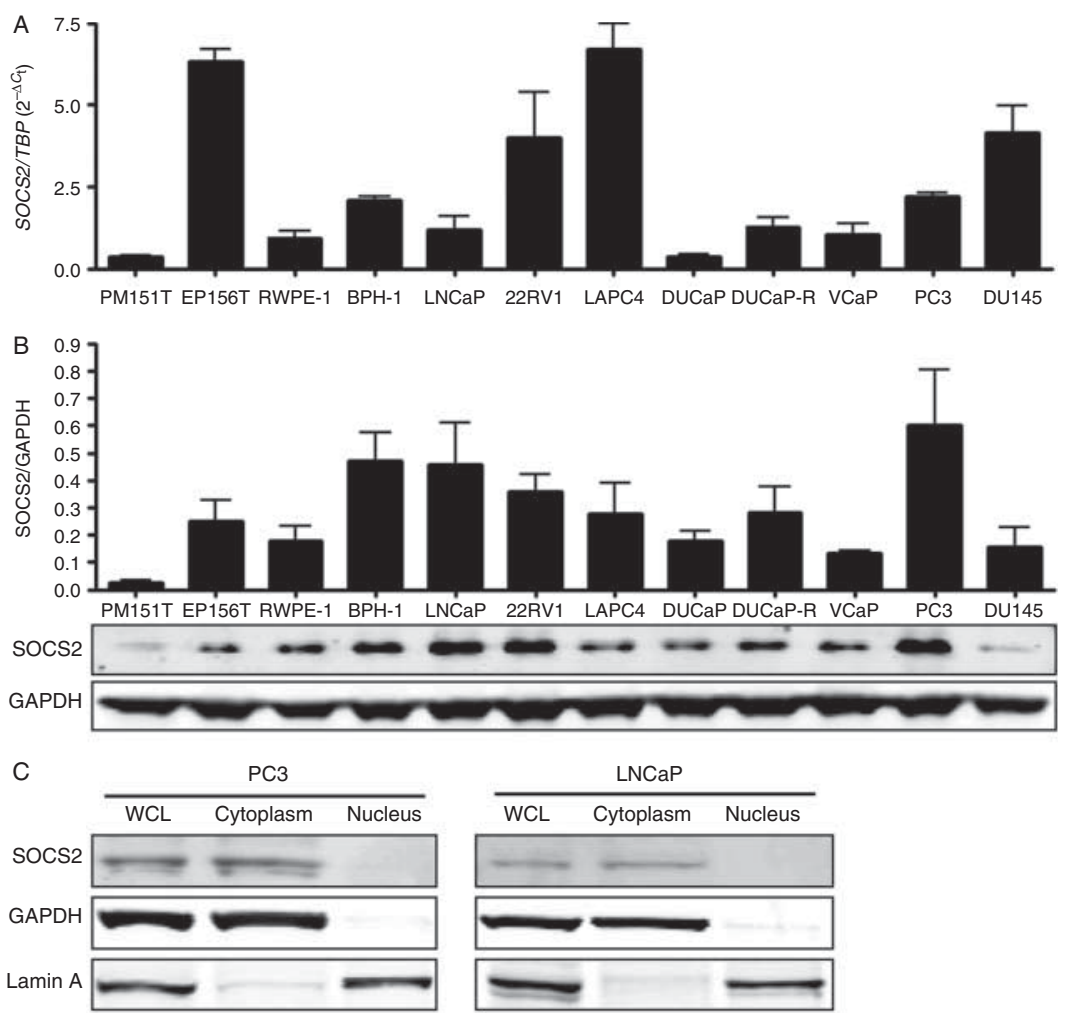

\section{Figure 2}

SOCS2 is expressed in the cytoplasm of prostate cell lines. (A) SOCS2 mRNA and (B) SOCS2 protein expression in benign and malignant prostate cell lines was assessed by GRT-PCR and western blotting respectively.

apoptosis and cell-cycle distribution. The percentage of apoptotic cells was slightly increased in PC3 and DU145 cells after SOCS2 silencing compared with the control cells. However, LNCaP cells were more sensitive and displayed a $40 \%$ apoptosis rate after SOCS2 knockdown (Fig. 5A). These findings were confirmed by the measurement of cleaved PARP (cPARP) levels by western blotting. As expected, LNCaP shSOCS2 cells exhibited a massive increase in CPARP levels compared with the respective controls, while this effect was less distinct in PC3 and DU145 cells (Fig. 5B). To further uncover the molecular basis for altered cell proliferation after SOCS2 knockdown, we analyzed cell-cycle distribution in the control as well as shSOCS2 cells. As has been mentioned above, LNCaP cell line responded with a massive increase in the subG1 proportion, which represents the apoptotic population (Supplementary Figure 3, see section on supplementary data given at the end of this article). However, we observed an altered cell-cycle distribution pattern in PC3 and DU145 cells after SOCS2 downregulation compared with the control cells (Fig. 5C). Statistical analysis revealed
Data represent mean values of three independent experiments. (C) SOCS2 subcellular localization was determined by western blotting after cytoplasmic and nuclear fractionation of PC3 and LNCaP cell lysates.

an S-phase growth arrest in SOCS2-depleted PC3 and DU145 cells and in addition an increase in the percentage of G2/M-phase cells in PC3 shSOCS2 cell line. The G0/G1phase proportion was significantly decreased in both cell lines after SOCS2 knockdown (Fig. 5D).

\section{SOCS2 expression is upregulated by androgens}

Finally, we aimed to provide a possible explanation for the significantly increased SOCS2 expression in the malignant tissue of PCa patients. AR is able to activate STAT5 (Tan et al. 2008), which in turn has been shown to upregulate SOCS2 in head-and-neck squamous cell carcinoma (HNSCC; Sen et al. 2011). Therefore, we hypothesized that SOCS2 expression might be influenced upon androgenic stimulation in PCa. To address this issue, we used Affymetrix GeneChip expression data of LNCaP, DUCaP, and VCaP cells cultured in the absence or presence of R1881. SOCS2 was identified as an androgen-regulated gene (Fig. 6A). We confirmed this finding also at the mRNA and protein levels, demonstrating androgenic

Published by Bioscientifica Ltd 
A

PC3

DU145

LNCaP
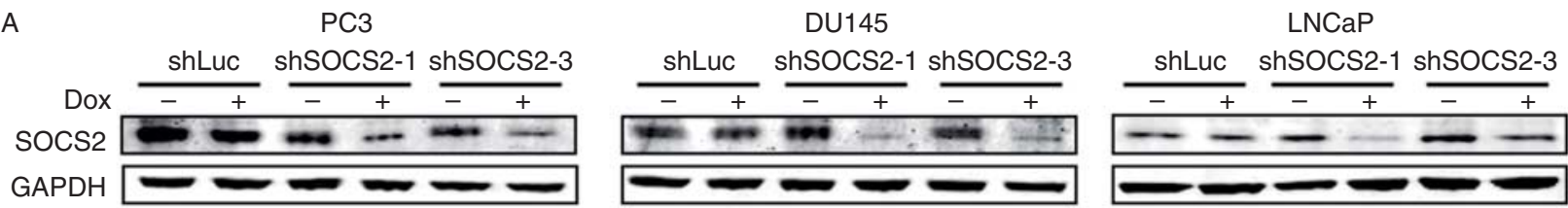

B

PC3

DU145

LNCaP
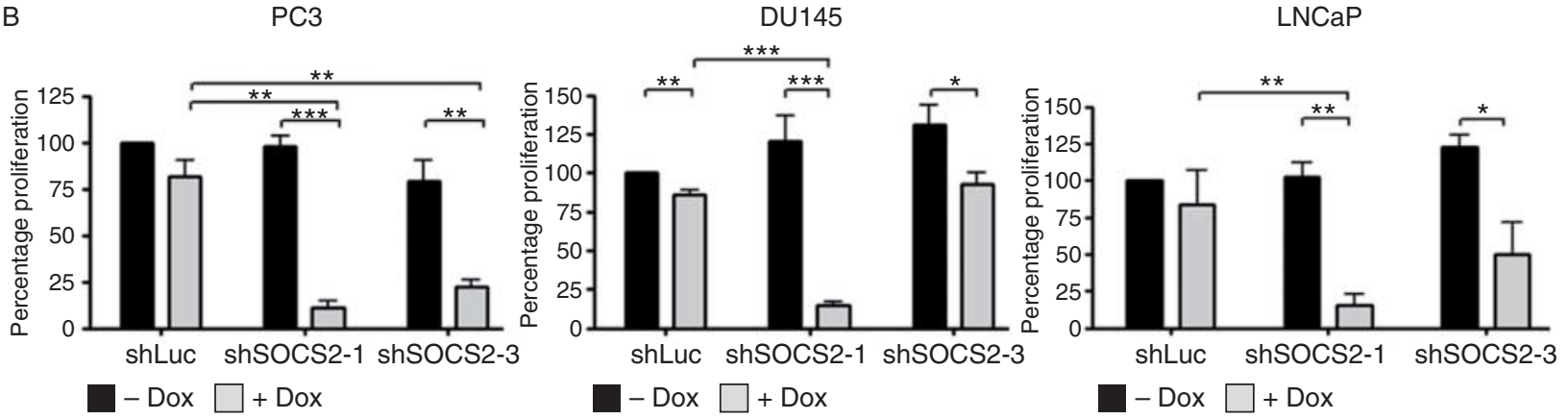

C

PC3

DU145
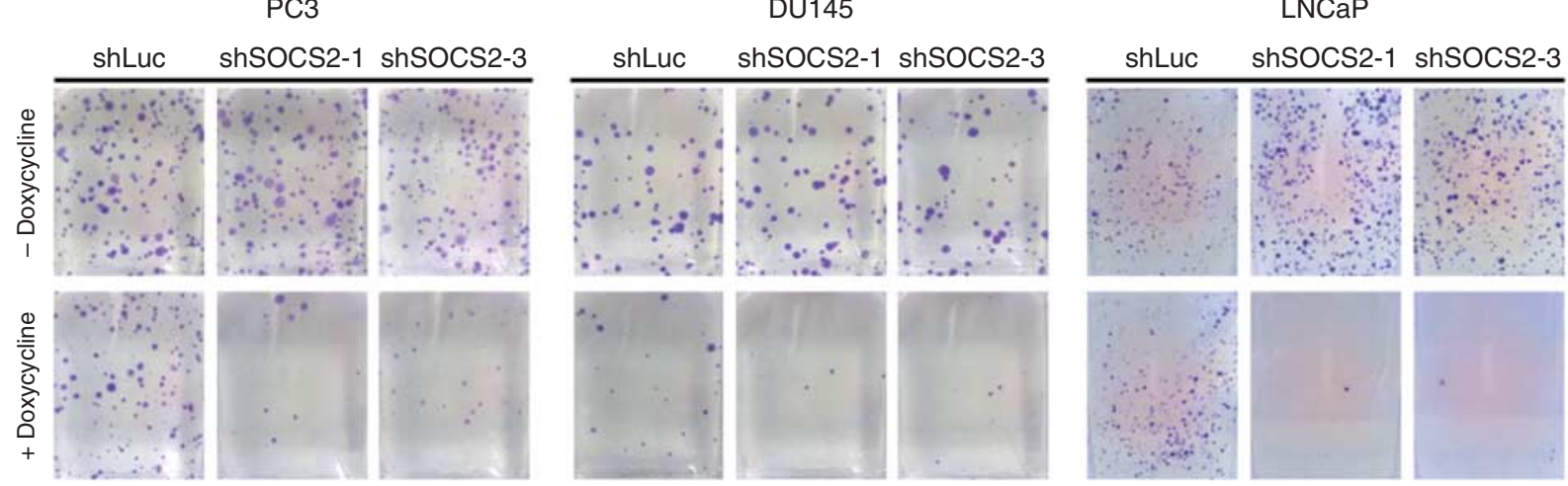

D

PC3

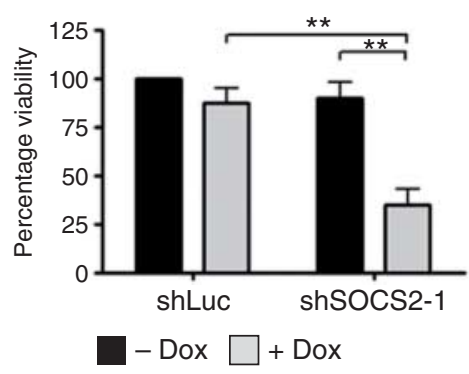

DU145
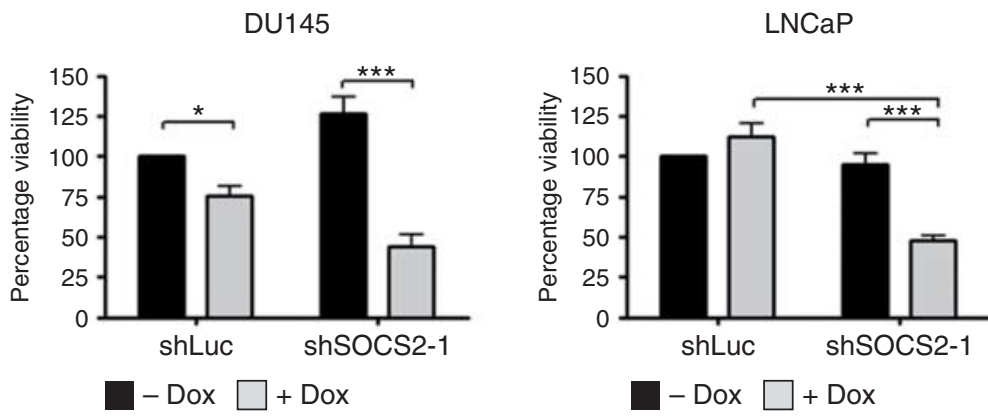

Figure 3

SOCS2 downregulation decelerates cell growth. (A) SOCS2 downregulation after stable transfection of PC3, DU145, and LNCaP cells with doxycyclineinducible shRNA sequences against SOCS2 (shSOCS2-1 and shSOCS2-3) or luciferase (shLuc). A representative western blot after 6 days of doxycycline treatment is shown. (B) Proliferation after SOCS2 downregulation was assessed by the measurement of $\left[{ }^{3} \mathrm{H}\right]$ thymidine incorporation.

SOCS2 upregulation in a dose-dependent manner in LNCaP cells. Furthermore, treatment with the antiandrogen bicalutamide was sufficient to reverse this effect (Fig. 6B). Androgen-induced SOCS2 expression increase was in addition time dependent and peaked between 8 and

http://erc.endocrinology-journals.org
DOI: 10.1530/ERC-13-0446
(C) 2014 The authors Printed in Great Britain
Data represent means $\pm \mathrm{S} \mathrm{E} M$. from three independent experiments ( ${ }^{*} P<0.05 ; * * P<0.01$; and $* * * P<0.001 ; t$-test). (C) Colony formation ability was measured by clonogenic assay. (D) Viability after SOCS2 downregulation was measured using WST reagent. Data represent means \pm S E M from three independent experiments $(* P<0.05 ; * * P<0.01$; and $* * * P<0.001 ; t$-test).

$24 \mathrm{~h}$ in LNCaP, DUCaP, and VCaP cells (Fig. 6C). To further confirm androgen responsiveness of SOCS2, we expected that androgen withdrawal would result in a diminished SOCS2 expression. Hence, we depleted LAPC4 cells, which are usually grown in a medium containing 
A

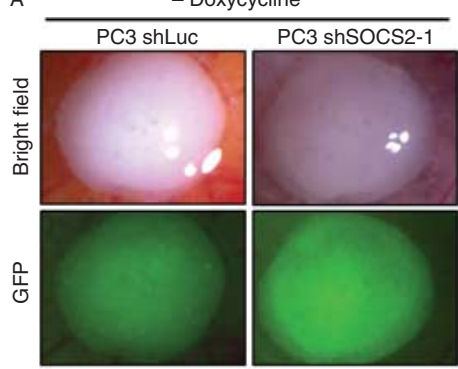

B

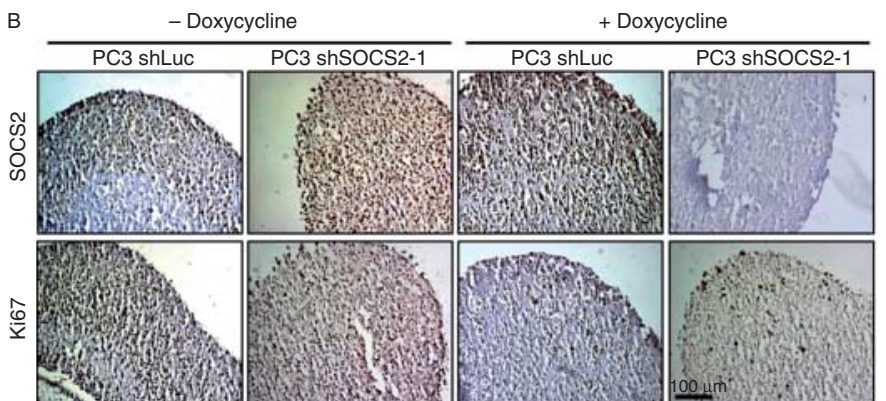

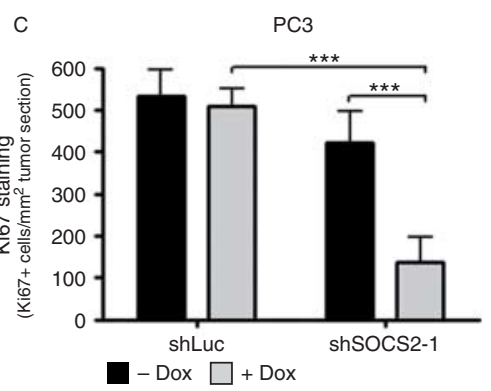

D

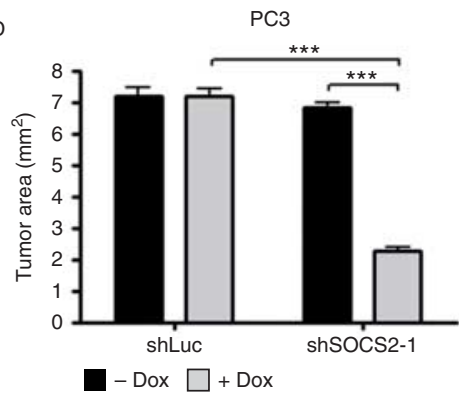

\section{Figure 4}

SOCS2 expression influences tumor growth in vivo. (A) Bright-field and fluorescence pictures of representative tumors obtained in a CAM assay. Before engraftment, the cells were pretreated with or without doxycycline for 6 days. (B) Immunohistochemical staining of tumor cross-sections for

DHT. As expected, we observed a significantly decreased SOCS2 expression in cells grown in the steroid-free medium, compared with cells cultured in the presence of DHT (Fig. 6D). Finally, we were able to translate these findings to the patients, demonstrating a significant correlation between SOCS2 and AR expression in patient samples (Fig. 6E).

\section{Discussion}

Deregulation of endogenous feedback inhibitors of JAK/ STAT signaling is well recognized in PCa and other cancers. We have previously demonstrated that SOCS1, SOCS3, and PIAS1 are upregulated in prostate tumors compared with benign tissue and have fundamental roles in proliferation and apoptosis (Neuwirt et al. 2009, Puhr et al. 2009, Hoefer et al. 2012). SOCS2 is hypermethylated in ovarian and breast cancers, in which its reduced expression is associated with the activation of STAT3, indicating an increased cytokine responsiveness in these tumors (Sutherland et al. 2004). SOCS2 mRNA has been found to be downregulated in pulmonary cancer, hepatocellular cancer and PCa (Wikman et al. 2002, Hendriksen et al. 2006, Qiu et al. 2013). On the other hand, SOCS2 acts as an oncogene in advanced stages of chronic myeloid
Ki67 and SOCS2. (C and D) Statistical analysis of Ki67-positive cells $/ \mathrm{cm}^{2}$ tumor cross-section (C) and tumor area (D) of the CAM onplants. Data represent means \pm s.D. of five onplants/treatment, done in two independent experiments ( ${ }^{*} P<0.05$ and $* * * P<0.001$; $t$-test).

leukemia as well as in precursors of anal cancer, where it is significantly upregulated (Arany et al. 2001, Schultheis et al. 2002). However, other studies that have investigated SOCS2 in PCa have addressed different aspects of SOCS2 function and have been carried out under different experimental conditions (Hendriksen et al. 2006, Iglesias-Gato et al. 2013, Zhu et al. 2013).

In the present study, we investigated SOCS2 expression patterns in benign and low- and high-Gleason score tumor samples as well as in prostate cell lines. Differences between SOCS2 mRNA and protein levels observed in the cell lines are not surprising, because SOCS2 protein is highly unstable as a consequence of active degradation (Siewert et al. 1999). In tissue samples, we detected significantly increased SOCS2 levels in malignant areas and were furthermore able to positively correlate SOCS2 expression with increasing Gleason scores. In addition, we could demonstrate that patients with a high SOCS2 expression are more likely to experience biochemical tumor relapse. These findings are partially in line with those of a recent study (Zhu et al. 2013), which identified an increased SOCS2 expression in malignant vs benign tissue. However, in contrast to our findings, that study observed a significant upregulation only in low-Gleason score tumors, whereas in

Published by Bioscientifica Ltd. 

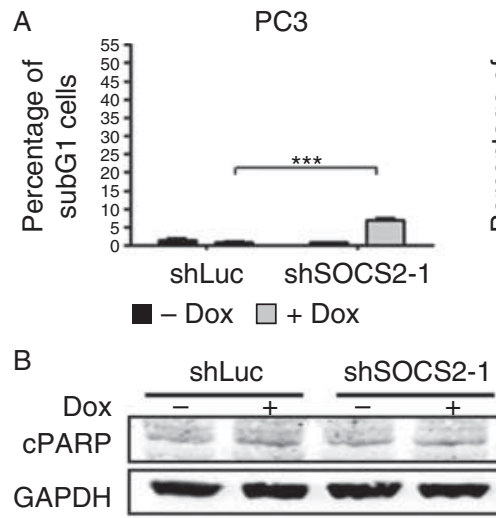

C

PC3
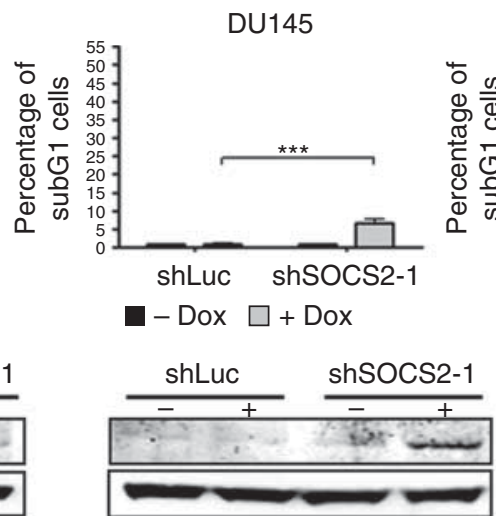
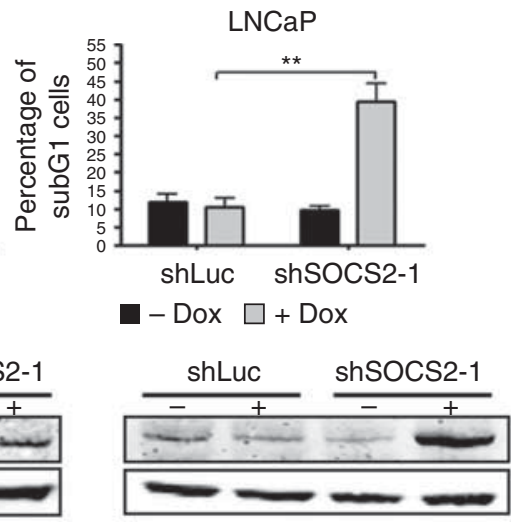

DU145
shLuc
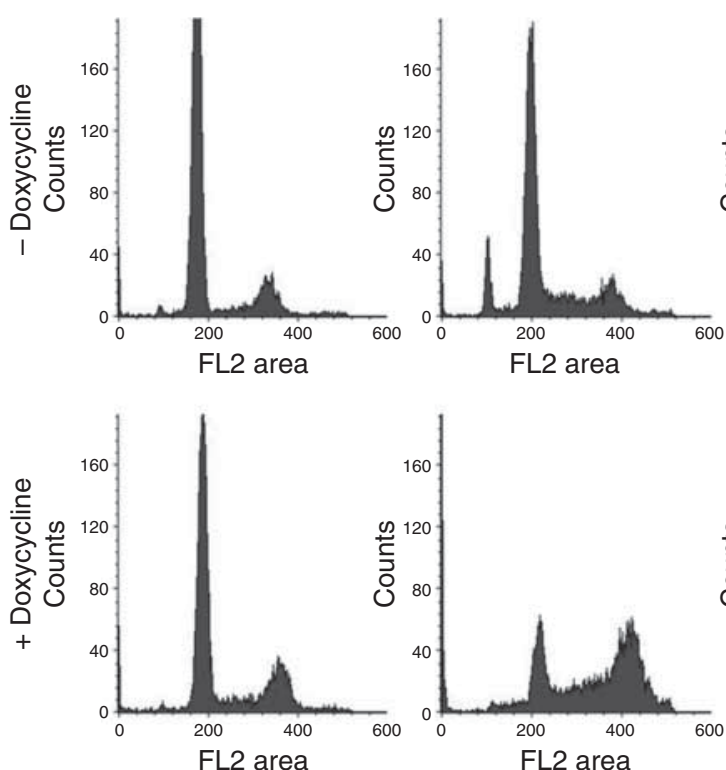

shSOCS2-1

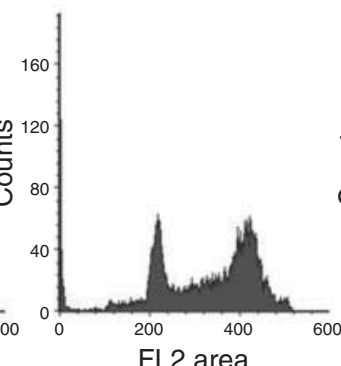

shLuc

shSOCS2-1
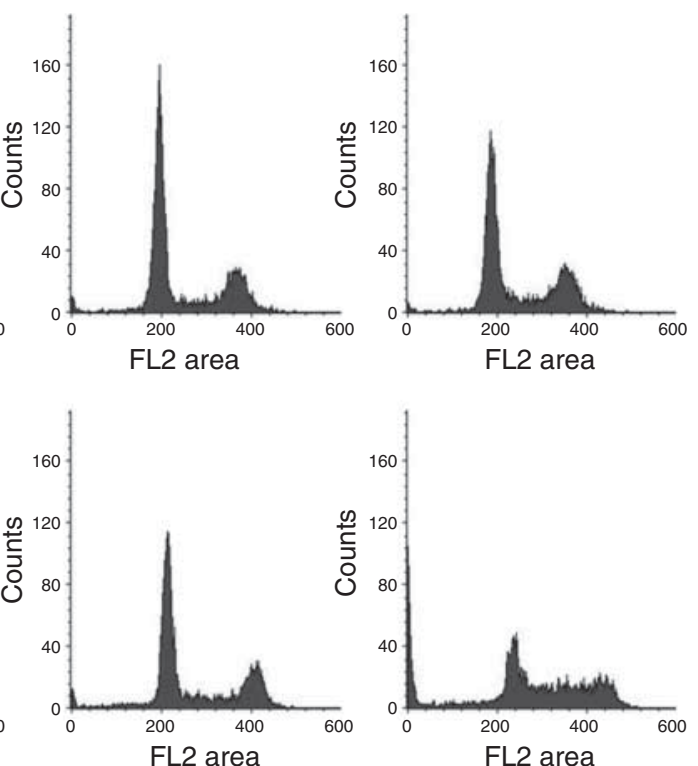

D
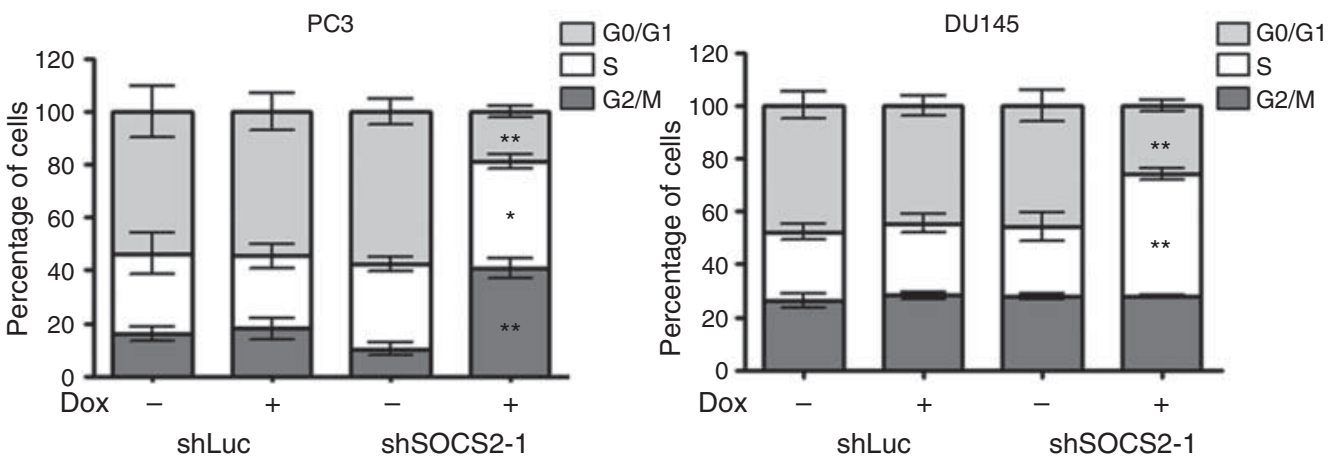

\section{Figure 5}

SOCS2 expression influences apoptosis and cell-cycle progression. (A and B) Apoptosis after SOCS2 downregulation was assessed by flow cytometry after PI staining (A), as well as CPARP measurement by western blotting (B) after 6 days of doxycycline treatment. Data represent means \pm S.E.M. from three independent experiments $(* * P<0.01$ and $* * * P<0.001 ; t$-test $)$.
(C) Representative histograms and (D) statistical analysis of cell-cycle distribution after SOCS2 downregulation as measured by flow cytometry. Data represent means \pm s.E.M. from three independent experiments ( $* * P<0.01$; and $* * * P<0.001 ; t$-test). http://erc.endocrinology-journals.org DOI: 10.1530/ERC-13-0446
(C) 2014 The authors Printed in Great Britain
Published by Bioscientifica Ltd 
high-Gleason score tumors only a trend toward a high SOCS2 expression was observed. SOCS2 expression was found to be associated with longer relapse-free survival. Besides ethnic differences, a diverse designation of tumors into low- and high-Gleason score groups, as well as different IHC scoring methods, might explain these discrepancies. As SOCS2 is an androgen-regulated gene, ethnic differences between the study populations may be important for the analysis of data. Although more studies comparing AR target gene expression in different ethnic groups have to be carried out, one can expect that differences occur in certain tumor subgroups as a consequence of dissimilar AR transcriptional activities. Nevertheless, the generally elevated SOCS levels found in PCa were consistently observed in two independent patient cohorts. Furthermore, it should be mentioned that Iglesias-Gato et al. have very recently reported a higher SOCS2 immunoreactivity in parallel with a Gleason score increase in a Swedish population (2013).

In concordance with the tissue expression profile, our functional assays point to a potential growth-promoting activity of SOCS2 in PCa. First, SOCS2 downregulation leads to a significantly diminished tumor growth in vivo. Secondly, SOCS2 knockdown results in a substantial decrease in cell proliferation and clonogenicity in ARnegative and -positive cell lines. We could link this growth inhibition to S-phase and G2/M-phase cell-cycle arrests with a slight increase in apoptosis in AR-negative PC3 and DU145 cells. Interestingly, SOCS2-depleted LNCaP cells exhibit a dramatic increase in apoptosis, suggesting an additional role for SOCS2 in AR-positive cells, which renders them more sensitive to SOCS2 knockdown.

The concept of SOCS2 as a growth promoter rather than as an inhibitor is supported by data obtained from other studies. Both Socs2 knockout and transgenic mice display gigantism (Metcalf et al. 2000, Greenhalgh et al. 2002). This observation can be explained by the circumstance that SOCS2 plays a dual role in growth regulation, depending on its concentration. At low levels, SOCS2 inhibits several cascades such as $\mathrm{GH}$, prolactin, and IL signaling, whereas at high levels, SOCS2 restores or potentiates responsiveness to these growth factors (Favre et al. 1999, Pezet et al. 1999, Tannahill et al. 2005, Piessevaux et al. 2006). In this context, SOCS2 has been demonstrated to enhance GH, IL2, and IL3 signals and subsequent proliferation via proteasomal degradation of other SOCS members, thereby overcoming their inhibitory effects (Favre et al. 1999, Tannahill et al. 2005). These findings suggest SOCS2 to be a positive regulator of proliferation when expressed at high levels. PCa is characterized by the deregulation of several signaling pathways including GH, prolactin, IL6, and the IGF/insulin axis (Roberts 2004, Monti et al. 2007, Cox et al. 2009,
A

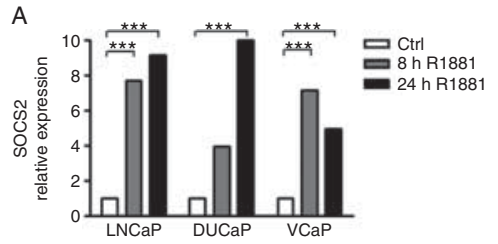

B

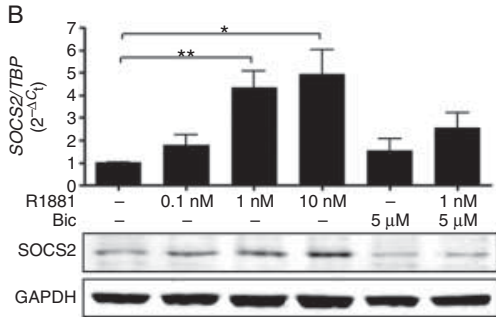

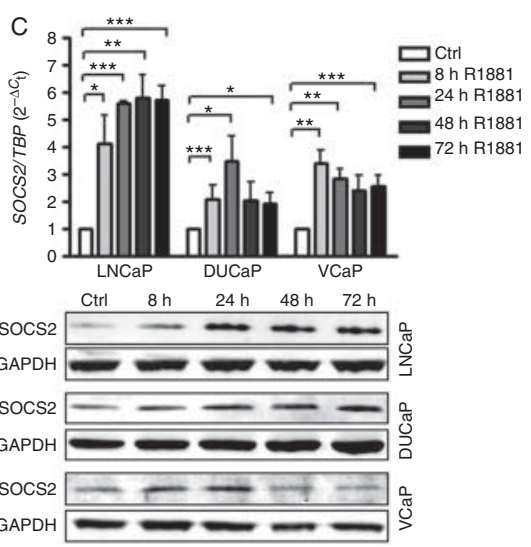

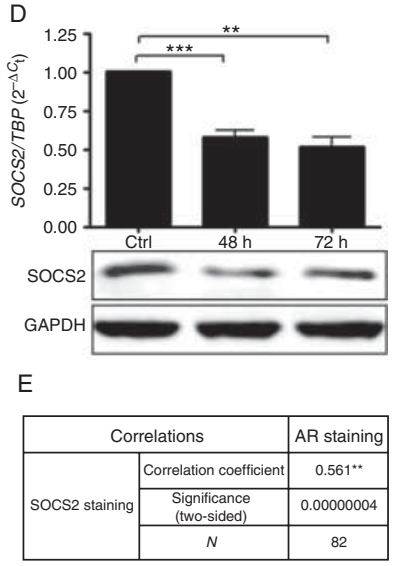

\section{Figure 6}

SOCS2 is upregulated upon androgenic stimulation. (A) Affymetrix data of R1881-treated LNCaP, DUCaP, and VCaP cells ( $* * * P<0.001 ; t$-test). (B) qRT-PCR data and representative western blot of LNCaP cells treated with increasing concentrations of R1881 and bicalutamide (Bic) or a combination of both for $24 \mathrm{~h}$. Data represent mean values of three independent experiments ( ${ }^{*} P<0.05 ;{ }^{*} P<0.01 ; t$-test). (C) qRT-PCR data and representative western blots of LNCaP, DUCaP, and VCaP cells treated with $1 \mathrm{nM}$ of $\mathrm{R} 1881$ for $8,24,48$, and $72 \mathrm{~h}$. Data represent mean values of three independent experiments $(* P<0.05$; $* * P<0.01$; and $* * * P<0.001$; t-test). (D) qRT-PCR data and representative western blot of LAPC4 cells grown in steroid-free medium with the addition of $100 \mathrm{nM}$ dihydrotestosterone (DHT) (ctrl) or after 24 or $48 \mathrm{~h}$ of DHT depletion. Data represent mean values of three independent experiments $(* * P<0.01 ; * * * P<0.001$, $t$-test). (E) Pearson's correlation analysis results for SOCS2 and AR staining in malignant tissue samples of the TMA. http://erc.endocrinology-journals.org DOI: 10.1530/ERC-13-0446
(C) 2014 The authors Printed in Great Britain
Published by Bioscientifica Ltd 
Culig 2011, Goffin et al. 2011, Culig \& Puhr 2012, Nakonechnaya et al. 2013), which can induce SOCS2 expression (Trengove \& Ward 2013). We therefore hypothesize that in PCa SOCS2 is generally highly expressed as a consequence of these oncogenic events and thus acts as an accelerator of proliferative signals in this disease. Hence, it is not surprising that SOCS2 knockdown in PCa cells resulted in growth inhibition.

In addition, we proved that SOCS2 is upregulated by androgens in AR-positive cell lines. SOCS2 is induced upon androgenic stimulation in a dose- and timedependent manner at both mRNA and protein levels. Androgen responsiveness of SOCS2 was further confirmed in an experimental setting, where androgens were depleted. Although we cannot exclude alternative mechanisms, a regulation via STAT5 might be a possible explanation. AR increases the transcriptional activity of STAT5 and vice versa (Tan et al. 2008). STAT5 has been shown to stimulate SOCS2 expression in HNSCC (Sen et al. 2011). Furthermore, SOCS2 has been identified as a direct STAT5 target in the liver (Vidal et al. 2007). On the basis of these data and our results, we hypothesize that in AR-positive cells SOCS2 expression is increased due to STAT5 activation following androgen stimulation. This mechanism provides a possible explanation for the elevated SOCS2 expression in prostate tumors, which frequently harbor a highly active androgen signaling (Buchanan et al. 2001, Lonergan \& Tindall 2011).

While this manuscript was in preparation, IglesiasGato et al. (2013) reported that SOCS2 antagonizes the oncogenic events caused by GH in PCa. It should be mentioned that differences in the results of the two studies may be explained by the presence or absence of GH in the experiments carried out. In the present study, all the experiments were carried out in cells not treated with $\mathrm{GH}$. On the whole, our study is the first to link increased SOCS2 expression in tissue samples of PCa patients with a growth-promoting role for SOCS2 in vitro and in vivo. Furthermore, we demonstrated androgen responsiveness of SOCS2 in AR-positive cell lines, providing a mechanistic explanation for the high SOCS2 expression in PCa via androgenic stimulation. These findings render SOCS2 an interesting candidate for further investigations to clarify specific pathways involved in SOCS2-mediated effects on PCa cell growth.

\section{Supplementary data}

This is linked to the online version of the paper at http://dx.doi.org/10.1530/ ERC-13-0446.

http://erc.endocrinology-journals.org DOI: 10.1530/ERC-13-0446
(C) 2014 The authors Printed in Great Britain
Declaration of interest

The authors declare that there is no conflict of interest that could be perceived as prejudicing the impartiality of the research reported.

\section{Funding}

This work was funded by the Austrian Cancer Society/Tirol, the intramural funding program of the Medical University of Innsbruck for young scientists MUI-START, Project 2010012007, and FWF grant P 25639-B19 (to M Puhr), and FWF grant W1101 (to Z Culig).

\section{Author contribution statement}

$\mathrm{J}$ Hoefer carried out all the in vitro experiments except the Affymetrix analysis and wrote the manuscript. J Kern and E Gunsilius carried out and analyzed the CAM assay. P Ofer established shSOCS2 and shLuc LNCaP cell lines. I E Eder and J Rainer conducted the Affymetrix experiment. G Schäfer scored IHC of the Innsbruck-TMA in cooperation with MP. D Dietrich and $G$ Kristiansen planned and coordinated the methylation analysis and IHC staining of the Bonn-TMA. S Geley cloned the plasmids for shRNA transfection. H Klocker was responsible for the generation of the Innsbruck-TMA. Z Culig supervised J Hoefer and helped writing the manuscript. M Puhr supervised J Hoefer, established shSOCS2 and shLuc PC3 and DU145 cell lines, organized the in vivo experiments, analyzed the Innsbruck-TMA and helped writing the manuscript. In addition, all the co-authors improved the manuscript and approved its final version. M Puhr and Z Culig are joint corresponding authors.

\section{Acknowledgements}

The authors thank Irma Sottsas, Karin Unterberger, Seher Aktekin, and Magda Röhler for generation and IHC staining of the TMAs, Dr Verena Seiler for scoring the Bonn-TMA, Cornelia Heis for IHC staining of the CAM tumors, Veronika Rauch for help with viral infections, and Eberhard Steiner for statistical analyses of patient data.

\section{References}

Arany I, Muldrow M \& Tyring SK 2001 The endogenous interferon system in anal squamous epithelial lesions with different grades from HIV-positive individuals. International Journal of STD \& AIDS 12 229-233. (doi:10.1258/0956462011922977)

Armstrong PB, Quigley JP \& Sidebottom E 1982 Transepithelial invasion and intramesenchymal infiltration of the chick embryo chorioallantois by tumor cell lines. Cancer Research 42 1826-1837.

Bellezza I, Neuwirt H, Nemes C, Cavarretta IT, Puhr M, Steiner H, Minelli A, Bartsch G, Offner F, Hobisch A et al. 2006 Suppressor of cytokine signaling-3 antagonizes cAMP effects on proliferation and apoptosis and is expressed in human prostate cancer. American Journal of Pathology 169 2199-2208. (doi:10.2353/ajpath.2006.060171)

Buchanan G, Irvine RA, Coetzee GA \& Tilley WD 2001 Contribution of the androgen receptor to prostate cancer predisposition and progression. Cancer Metastasis Reviews 20 207-223. (doi:10.1023/ A:1015531326689)

Cox ME, Gleave ME, Zakikhani M, Bell RH, Piura E, Vickers E, Cunningham M, Larsson O, Fazli L \& Pollak M 2009 Insulin receptor expression by human prostate cancers. Prostate 69 33-40. (doi:10.1002/pros.20852)

Croker BA, Kiu H \& Nicholson SE 2008 SOCS regulation of the JAK/STAT signalling pathway. Seminars in Cell \& Developmental Biology 19 414-422. (doi:10.1016/j.semcdb.2008.07.010)

Published by Bioscientifica Ltd. 
Culig Z 2011 Cytokine disbalance in common human cancers. Biochimica et Biophysica Acta 1813 308-314. (doi:10.1016/j.bbamcr.2010.12.010)

Culig Z 2013 Suppressors of cytokine signalling-3 and -1 in human carcinogenesis. Frontiers in Bioscience 5 277-283. (doi:10.2741/S372)

Culig Z \& Puhr M 2012 Interleukin-6: a multifunctional targetable cytokine in human prostate cancer. Molecular and Cellular Endocrinology 360 52-58. (doi:10.1016/j.mce.2011.05.033)

Deryugina EI \& Quigley JP 2008 Chapter 2. Chick embryo chorioallantoic membrane models to quantify angiogenesis induced by inflammatory and tumor cells or purified effector molecules. Methods in Enzymology 444 21-41.

Detre S, Saclani Jotti G \& Dowsett M 1995 A "quickscore" method for immunohistochemical semiquantitation: validation for oestrogen receptor in breast carcinomas. Journal of Clinical Pathology 48 876-878. (doi:10.1136/jcp.48.9.876)

Dey BR, Spence SL, Nissley P \& Furlanetto RW 1998 Interaction of human suppressor of cytokine signaling (SOCS)-2 with the insulin-like growth factor-I receptor. Journal of Biological Chemistry 273 24095-24101. (doi:10.1074/jbc.273.37.24095)

Dietrich D, Hasinger O, Liebenberg V, Field JK, Kristiansen G \& Soltermann A 2012 DNA methylation of the homeobox genes PITX2 and SHOX2 predicts outcome in non-small-cell lung cancer patients. Diagnostic Molecular Pathology 21 93-104. (doi:10.1097/PDM.0b013e318240503b)

Dutt SS \& Gao AC 2009 Molecular mechanisms of castration-resistant prostate cancer progression. Future Oncology 5 1403-1413. (doi:10.2217/fon.09.117)

Endo TA, Masuhara M, Yokouchi M, Suzuki R, Sakamoto H, Mitsui K, Matsumoto A, Tanimura S, Ohtsubo M, Misawa H et al. 1997 A new protein containing an $\mathrm{SH} 2$ domain that inhibits JAK kinases. Nature 387 921-924. (doi:10.1038/43213)

Favre H, Benhamou A, Finidori J, Kelly PA \& Edery M 1999 Dual effects of suppressor of cytokine signaling (SOCS-2) on growth hormone signal transduction. FEBS Letters 453 63-66. (doi:10.1016/ S0014-5793(99)00681-X)

Gentleman RC, Carey VJ, Bates DM, Bolstad B, Dettling M, Dudoit S, Ellis B, Gautier L, Ge Y, Gentry J et al. 2004 Bioconductor: open software development for computational biology and bioinformatics. Genome Biology 5 R80. (doi:10.1186/gb-2004-5-10-r80)

Goffin V, Hoang DT, Bogorad RL \& Nevalainen MT 2011 Prolactin regulation of the prostate gland: a female player in a male game. Nature Reviews. Urology 8 597-607. (doi:10.1038/nrurol.2011.143)

Greenhalgh CJ, Metcalf D, Thaus AL, Corbin JE, Uren R, Morgan PO, Fabri LJ, Zhang JG, Martin HM, Willson TA et al. 2002 Biological evidence that SOCS-2 can act either as an enhancer or suppressor of growth hormone signaling. Journal of Biological Chemistry 277 40181-40184. (doi:10.1074/ jbc.C200450200)

Heinrich PC, Behrmann I, Haan S, Hermanns HM, Muller-Newen G \& Schaper F 2003 Principles of interleukin (IL)-6-type cytokine signalling and its regulation. Biochemical Journal 374 1-20. (doi:10.1042/ BJ20030407)

Hendriksen PJ, Dits NF, Kokame K, Veldhoven A, van Weerden WM, Bangma CH, Trapman J \& Jenster G 2006 Evolution of the androgen receptor pathway during progression of prostate cancer. Cancer Research 66 5012-5020. (doi:10.1158/0008-5472.CAN-05-3082)

Hoefer J, Schafer G, Klocker H, Erb HH, Mills IG, Hengst L, Puhr M \& Culig Z 2012 PIAS1 is increased in human prostate cancer and enhances proliferation through inhibition of p21. American Journal of Pathology 180 2097-2107. (doi:10.1016/j.ajpath.2012.01.026)

Iglesias-Gato D, Chuan YC, Wikstrom P, Augsten S, Jiang N, Niu Y, Seipel A, Danneman D, Vermeij M, Fernandez-Perez L et al. 2013 SOCS2 mediates the crosstalk between androgen and growth hormone signaling in prostate cancer. Carcinogenesis [in press].

Jemal A, Siegel R, Xu J \& Ward E 2011 Cancer statistics 2010. CA: A Cancer Journal for Clinicians 60 277-300. (doi:10.3322/caac.20073)

Kamura T, Sato S, Haque D, Liu L, Kaelin WG Jr, Conaway RC \& Conaway JW 1998 The Elongin BC complex interacts with the conserved SOCS-box motif present in members of the SOCS, ras, WD-40 repeat, and ankyrin repeat families. Genes and Development 12 3872-3881. (doi:10.1101/gad.12.24.3872)

Kamura T, Maenaka K, Kotoshiba S, Matsumoto M, Kohda D, Conaway RC, Conaway JW \& Nakayama KI 2004 VHL-box and SOCS-box domains determine binding specificity for Cul2-Rbx1 and Cul5-Rbx2 modules of ubiquitin ligases. Genes and Development 18 3055-3065. (doi:10.1101/ gad.1252404)

Kogan I, Goldfinger N, Milyavsky M, Cohen M, Shats I, Dobler G, Klocker H, Wasylyk B, Voller M, Aalders T et al. 2006 hTERT-immortalized prostate epithelial and stromal-derived cells: an authentic in vitro model for differentiation and carcinogenesis. Cancer Research 66 3531-3540. (doi:10.1158/0008-5472.CAN-05-2183)

Kunzi-Rapp K, Genze F, Kufer R, Reich E, Hautmann RE \& Gschwend JE 2001 Chorioallantoic membrane assay: vascularized 3-dimensional cell culture system for human prostate cancer cells as an animal substitute model. Journal of Urology 166 1502-1507. (doi:10.1016/S0022$5347(05) 65820-\mathrm{X})$

Larsen L \& Ropke C 2002 Suppressors of cytokine signalling: SOCS. APMIS: Acta Pathologica, Microbiologica, et Immunologica Scandinavica 110 833-844. (doi:10.1034/j.1600-0463.2002.1101201.x)

Locke JA, Guns ES, Lubik AA, Adomat HH, Hendy SC, Wood CA, Ettinger SL, Gleave ME \& Nelson CC 2008 Androgen levels increase by intratumoral de novo steroidogenesis during progression of castration-resistant prostate cancer. Cancer Research 68 6407-6415. (doi:10.1158/ 0008-5472.CAN-07-5997)

Lonergan PE \& Tindall DJ 2011 Androgen receptor signaling in prostate cancer development and progression. Journal of Carcinogenesis 1020. (doi:10.4103/1477-3163.83937)

Martowicz A, Rainer J, Lelong J, Spizzo G, Gastl G \& Untergasser G 2013 EpCAM overexpression prolongs proliferative capacity of primary human breast epithelial cells and supports hyperplastic growth. Molecular Cancer 12 56. (doi:10.1186/1476-4598-12-56)

Metcalf D, Greenhalgh CJ, Viney E, Willson TA, Starr R, Nicola NA, Hilton DJ \& Alexander WS 2000 Gigantism in mice lacking suppressor of cytokine signalling-2. Nature 405 1069-1073. (doi:10.1038/35016611)

Monti S, Proietti-Pannunzi L, Sciarra A, Lolli F, Falasca P, Poggi M, Celi FS \& Toscano V 2007 The IGF axis in prostate cancer. Current Pharmaceutical Design 13 719-727. (doi:10.2174/138161207780249128)

Naka T, Narazaki M, Hirata M, Matsumoto T, Minamoto S, Aono A, Nishimoto N, Kajita T, Taga T, Yoshizaki K et al. 1997 Structure and function of a new STAT-induced STAT inhibitor. Nature 387 924-929. (doi:10.1038/43219)

Nakonechnaya AO, Jefferson HS, Chen X \& Shewchuk BM 2013 Differential effects of exogenous and autocrine growth hormone on LNCaP prostate cancer cell proliferation and survival. Journal of Cellular Biochemistry 114 1322-1335. (doi:10.1002/jcb.24473)

Neuwirt H, Puhr M, Cavarretta IT, Mitterberger M, Hobisch A \& Culig Z 2007 Suppressor of cytokine signalling-3 is up-regulated by androgen in prostate cancer cell lines and inhibits androgen-mediated proliferation and secretion. Endocrine-Related Cancer 14 1007-1019. (doi:10.1677/ ERC-07-0172)

Neuwirt H, Puhr M, Santer FR, Susani M, Doppler W, Marcias G, Rauch V, Brugger M, Hobisch A, Kenner L et al. 2009 Suppressor of cytokine signaling (SOCS)-1 is expressed in human prostate cancer and exerts growth-inhibitory function through down-regulation of cyclins and cyclin-dependent kinases. American Journal of Pathology 174 1921-1930. (doi:10.2353/ajpath.2009.080751)

Pezet A, Favre H, Kelly PA \& Edery M 1999 Inhibition and restoration of prolactin signal transduction by suppressors of cytokine signaling. Journal of Biological Chemistry 274 24497-24502. (doi:10.1074/ jbc.274.35.24497)

Pfeiffer MJ, Mulders PF \& Schalken JA 2010 An in vitro model for preclinical testing of endocrine therapy combinations for prostate cancer. Prostate 70 1524-1532. (doi:10.1002/pros.21187) 
Pierconti F, Martini M, Pinto F, Cenci T, Capodimonti S, Calarco A, Bassi PF \& Larocca LM 2011 Epigenetic silencing of SOCS3 identifies a subset of prostate cancer with an aggressive behavior. Prostate 71 318-325. (doi:10.1002/pros.21245)

Piessevaux J, Lavens D, Montoye T, Wauman J, Catteeuw D, Vandekerckhove J, Belsham D, Peelman F \& Tavernier J 2006 Functional cross-modulation between SOCS proteins can stimulate cytokine signaling. Journal of Biological Chemistry 281 32953-32966. (doi:10.1074/jbc.M600776200)

Puhr M, Santer FR, Neuwirt H, Susani M, Nemeth JA, Hobisch A, Kenner L \& Culig Z 2009 Down-regulation of suppressor of cytokine signaling-3 causes prostate cancer cell death through activation of the extrinsic and intrinsic apoptosis pathways. Cancer Research 69 7375-7384. (doi:10.1158/0008-5472.CAN-09-0806)

Puhr M, Santer FR, Neuwirt H, Marcias G, Hobisch A \& Culig Z 2010 SOCS-3 antagonises the proliferative and migratory effects of fibroblast growth factor- 2 in prostate cancer by inhibition of p44/p42 MAPK signalling. Endocrine-Related Cancer 17 525-538. (doi:10.1677/ERC-10-0007)

Qiu X, Zheng J, Guo X, Gao X, Liu H, Tu Y \& Zhang Y 2013 Reduced expression of SOCS2 and SOCS6 in hepatocellular carcinoma correlates with aggressive tumor progression and poor prognosis. Molecular and Cellular Biochemistry 378 99-106. (doi:10.1007/s11010-013-1599-5)

Rainer J, Lelong J, Bindreither D, Mantinger C, Ploner C, Geley S \& Kofler R 2012 Research resource: transcriptional response to glucocorticoids in childhood acute lymphoblastic leukemia. Molecular Endocinology 26 178-193. (doi:10.1210/me.2011-1213)

Rico-Bautista E, Flores-Morales A \& Fernandez-Perez L 2006 Suppressor of cytokine signaling (SOCS) 2, a protein with multiple functions. Cytokine \& Growth Factor Reviews 17 431-439. (doi:10.1016/j.cytogfr. 2006.09.008)

Roberts CT Jr 2004 IGF-1 and prostate cancer. Novartis Foundation Symposium 262 193-199 discussion 199-204, 265-198.

Rui L, Yuan M, Frantz D, Shoelson S \& White MF 2002 SOCS-1 and SOCS-3 block insulin signaling by ubiquitin-mediated degradation of IRS1 and IRS2. Journal of Biological Chemistry 277 42394-42398. (doi:10.1074/ jbc.C200444200)

Ryo A, Suizu F, Yoshida Y, Perrem K, Liou YC, Wulf G, Rottapel R, Yamaoka S \& Lu KP 2003 Regulation of NF-kappaB signaling by Pin1-dependent prolyl isomerization and ubiquitin-mediated proteolysis of p65/RelA. Molecular Cell 12 1413-1426. (doi:10.1016/S1097-2765(03)00490-8)

Sadowski CL, Choi TS, Le M, Wheeler TT, Wang LH \& Sadowski HB 2001 Insulin induction of SOCS-2 and SOCS-3 mRNA expression in C2C12 skeletal muscle cells is mediated by Stat5*. Journal of Biological Chemistry 276 20703-20710. (doi:10.1074/jbc.M101014200)

Saw CL, Heng PW \& Liew CV 2008 Chick chorioallantoic membrane as an in situ biological membrane for pharmaceutical formulation development: a review. Drug Development and Industrial Pharmacy 34 1168-1177. (doi:10.1080/03639040801974295)

Schultheis B, Carapeti-Marootian M, Hochhaus A, Weisser A, Goldman JM \& Melo JV 2002 Overexpression of SOCS-2 in advanced stages of chronic myeloid leukemia: possible inadequacy of a negative feedback mechanism. Blood 99 1766-1775. (doi:10.1182/blood.V99.5.1766)

Sen B, Peng S, Woods DM, Wistuba I, Bell D, El-Naggar AK, Lai SY \& Johnson FM 2011 STAT5A-mediated SOCS2 expression regulates Jak2 and STAT3 activity following c-Src inhibition in head and neck squamous carcinoma. Clinical Cancer Research 18 127-139. (doi:10.1158/1078-0432.CCR-11-1889)

Siewert E, Muller-Esterl W, Starr R, Heinrich PC \& Schaper F 1999 Different protein turnover of interleukin-6-type cytokine signalling components.
European Journal of Biochemistry 265 251-257. (doi:10.1046/ j.1432-1327.1999.00719.x)

Sigl R, Wandke C, Rauch V, Kirk J, Hunt T \& Geley S 2009 Loss of the mammalian APC/C activator FZR1 shortens G1 and lengthens S phase but has little effect on exit from mitosis. Journal of Cell Science $\mathbf{1 2 2}$ 4208-4217. (doi:10.1242/jcs.054197)

Singh N, Hussain S, Bharadwaj M, Kakkar N, Singh SK \& Sobti RC 2012 Overexpression of signal transducer and activator of transcription (STAT-3 and STAT-5) transcription factors and alteration of suppressor of cytokine signaling (SOCS-1) protein in prostate cancer. Journal of Receptors and Signal Transduction Research 32 321-327. (doi:10.3109/ 10799893.2012.733885)

Starr R, Willson TA, Viney EM, Murray LJ, Rayner JR, Jenkins BJ, Gonda TJ, Alexander WS, Metcalf D, Nicola NA et al. 1997 A family of cytokineinducible inhibitors of signalling. Nature 387 917-921. (doi:10.1038/ 43206)

Sutherland KD, Lindeman GJ, Choong DY, Wittlin S, Brentzell L, Phillips W, Campbell IG \& Visvader JE 2004 Differential hypermethylation of SOCS genes in ovarian and breast carcinomas. Oncogene 23 7726-7733. (doi:10.1038/sj.onc.1207787)

Taizi M, Deutsch VR, Leitner A, Ohana A \& Goldstein RS 2006 A novel and rapid in vivo system for testing therapeutics on human leukemias. Experimental Hematology 34 1698-1708. (doi:10.1016/j.exphem. 2006.07.005)

Tan SH \& Nevalainen MT 2008 Signal transducer and activator of transcription 5A/B in prostate and breast cancers. Endocrine-Related Cancer 15 367-390. (doi:10.1677/ERC-08-0013)

Tan SH, Dagvadorj A, Shen F, Gu L, Liao Z, Abdulghani J, Zhang Y, Gelmann EP, Zellweger T, Culig Z et al. 2008 Transcription factor Stat5 synergizes with androgen receptor in prostate cancer cells. Cancer Research 68 236-248. (doi:10.1158/0008-5472.CAN-07-2972)

Tannahill GM, Elliott J, Barry AC, Hibbert L, Cacalano NA \& Johnston JA 2005 SOCS2 can enhance interleukin-2 (IL-2) and IL-3 signaling by accelerating SOCS3 degradation. Molecular and Cellular Biology 25 9115-9126. (doi:10.1128/MCB.25.20.9115-9126.2005)

Tavaszi J \& Budai P 2006 Toxicity study of agrochemicals on chorioallantoic membrane of the egg. Communications in Agricultural and Applied Biological Sciences 71 101-105.

Trengove MC \& Ward AC 2013 SOCS proteins in development and disease. American Journal of Clinical and Experimental Immunology 2 1-29.

Vidal OM, Merino R, Rico-Bautista E, Fernandez-Perez L, Chia DJ, Woelfle J, Ono M, Lenhard B, Norstedt G, Rotwein P et al. 2007 In vivo transcript profiling and phylogenetic analysis identifies suppressor of cytokine signaling 2 as a direct signal transducer and activator of transcription 5b target in liver. Molecular Endocinology 21 293-311. (doi:10.1210/ me.2006-0096)

Wang L, Zhang Z, Zhang R, Hafner MS, Wong HK, Jiao Z \& Chopp M 2004 Erythropoietin up-regulates SOCS2 in neuronal progenitor cells derived from SVZ of adult rat. Neuroreport 15 1225-1229. (doi:10.1097/ 01.wnr.0000127636.15181.c1)

Wikman H, Kettunen E, Seppanen JK, Karjalainen A, Hollmen J, Anttila S \& Knuutila S 2002 Identification of differentially expressed genes in pulmonary adenocarcinoma by using cDNA array. Oncogene $\mathbf{2 1}$ 5804-5813. (doi:10.1038/sj.onc.1205726)

Zhu JG, Dai QS, Han ZD, He HC, Mo RJ, Chen G, Chen YF, Wu YD, Yang SB, Jiang FN et al. 2013 Expression of SOCSs in human prostate cancer and their association in prognosis. Molecular and Cellular Biochemistry $\mathbf{3 8 1}$ 51-59. (doi:10.1007/s11010-013-1687-6)

Received in final form 22 November 2013

Accepted 25 November 2013

Made available online as an Accepted Preprint

26 November 2013 http://erc.endocrinology-journals.org

DOI: 10.1530/ERC-13-0446
(C) 2014 The authors Printed in Great Britain
Published by Bioscientifica Ltd 